\section{Consumer Preferences for Traceable Fruit and Vegetables and Their Influencing Factor in Indonesia}

\author{
Alim Setiawan Slamet ${ }^{\mathrm{a}, \mathrm{c}^{*}}$, Akira \\ Nakayasu $^{\text {b }}$
}

${ }^{a}$ The United Graduate School of Agricultural Science, Ehime University, Tarumi 3-5-7, Matsuyama 790-8566, Japan

${ }^{b}$ Faculty of Agriculture, Ehime University, Tarumi 3-5-7, Matsuyama 790-8566, Japan

${ }^{c}$ Department of Management, Faculty of Economic and

Management, Bogor Agricultural University, Kampus IPB Dramaga, Bogor 1688o, Indonesia

Received: September 29, 2015/ Accepted: February 6, 2017

\section{Abstract}

Through a consumer survey in the Jabodetabek region, this paper examines the characteristics of consumers who prefer traceable fresh fruits and vegetables (FFV) in Indonesia and analyses the influencing factors that help explain why consumers purchase traceable FFV. A descriptive analysis, factor analysis, and binary logistic regression model were used to analyse the data. The results of this study show that respondents who consider buying the traceable product are lower than respondents who prefer to buy the ordinary product. This study also indicates that well-educated consumers and modern shoppers are more likely to buy traceable FFV. Although consumer income level has no significant impact on the traceable preference, the respondents who are more sensitive to the price are less likely to buy the traceable FFV. Another important result is the positive attitude towards traceable product, food safety concern, environmental concern, importance consideration of certification \& product brand, and degree of trust. These are the factors which explain why consumers prefer to buy traceable FFV.

Keywords: consumers preferences; traceability; fruit and vegetable; binary logistic regression

Corresponding Author

Tel.: +628121866092 ; E-mail: alimss@ipb.ac.id
Abbreviations:

FFV : Fruit and Vegetable

FA : Factor Analysis

KMO : Kaiser-Mayer-Olkin

\section{Introduction}

As a result of the globalization of the food industry, the distance that food travels from producer to consumer has increased and it has become a significant challenge in maintaining safety and quality in the food supply chain [1]. A number of food crises, such as Bovine Spongiform Encephalopathy (BSE) or mad cow disease, Dioxin in chicken feed, milk adulterated with melamine, Foot-andMouth Disease (FMD), Listeria bacteria in apple and issues such as the use of Genetically Modified (GM) crops in foods have a serious impact on the credibility of the food industry [2][3]. For example, because of the Listeria outbreaks, Indonesian and other Asian countries banned the import of apples from California, USA, in early 2015. The negative effects of these incidences affect not only the supply side but also the demand side of the food chain. Consumers feel personally affected, become more sensitive, lose their trust in the producers and are likely to change their purchasing habits [3][4].

Ensuring food safety is becoming a global trend and in response to this issue, laws, policies and standards regarding food safety and quality management have progressed in the food industry [5][6]. As one to the tools adopted by the food industry to improve food safety, traceability plays an important role because it complies with legislation and it enhances the transparency and safety of the food system through the provisions of transparent trace back and track forward information as well as to boosting consumer confidence $[1][3][7]$. In many countries, traceability systems have been introduced as a legal requirement. For example, Japan introduced guidelines for a food traceability system in 2003, the United States introduced a traceability system with the 21 CFR820 regulations in 2004, and the European Union (EU) General Food Law made a traceability system for agricultural commodities to ensure food safety in products in 2005 a legal requirement [8]. In Indonesia, the legality of traceability systems is still limited. The government's role in ensuring food safety policies is under the Minister of Marine and Fisheries regulation No.: Per. o1/Men/2007 regarding the control system for quality assurance and food safety for fishery products. This regulation contains the principle of traceability, which stresses that businesses should include a label or some information that ensures that the traceability is in accordance with the requirements of certain types of products. 
Choosing what food to buy is the most common decision humans make and is determined by numerous interacting factors and interrelated determinants [9]. Before deciding to buy a product, consumers form quality expectations based on different attributes or cues which are usually tradeoffs of each other [10]. The attributes can be classified into search, experience and credence attributes according to the level of quality that can be discovered by the consumer at different stages [11]. Based on the Total Food Quality model, the stages of consumer decisionmaking process is distinguished by 'before' and 'after' purchase evaluations [12]. The pre-purchase evaluation in which both perceived intrinsic and extrinsic cues can affect consumer decision-making, the post-purchase out-come and can lead to repeat purchases. Search attributes (e.g. size, color, freshness, shape and price) can be ascertained before purchase, but most food products have a limited degree of search characteristics. Meanwhile, many characteristics of a food product (i.e. experience and credence attributes) cannot be ascertained before purchase [13]. Experience characteristics (e.g. flavor, taste) can only be ascertained after consuming the food product. Credence attributes (e.g. nutritional benefits, safety, and product origin) are also difficult to judge directly by consumers at the point of sale and even after the product has been consumed [14]. Traceability information (e.g. origin, increased prices, production methods, quality guarantee and best before date) might also contribute to increased consumer confidence in credence attributes (food safety, health, naturalness, quality, trust, control guarantee and environmental protection) [15], [16]. Furthermore, growing public awareness and concerns about the sustainability of some food production systems has meant that farmers, processors, and exporters are providing food to higher standards of environmental protection, quality, hygiene and traceability [17][18][19].

Although consumer perception of food traceability has been studied in many countries, little is known about consumer preference for traceable food in Indonesia, especially for fresh fruit and vegetable (FFV) products. This paper makes an attempt to fill this research gap. The purposes of this paper are: 1) to provide information on consumer preferences of traceable FFV in Indonesia; 2) to investigate consumer interest in information provided by product labels, and 3) to determine the factors which help explain consumers' preference for purchasing traceable FFV.

\section{Literature Review}

An earlier definition of traceability was provided by International Standard of Organization (ISO) in ISO 8402 (1994) that defined traceability as "the ability to retrieve history, use or location of an entity by means of recorded identifications" [20]. This definition is extended in ISO 9ooo (2005) standards as "the ability to trace the history, application or location of that which is under consideration" [21]. Later, EU through Regulation (EC) No. 178 / 2002 defining traceability as "the ability to trace and follow a food, feed, food - producing animal or substance intended to be, or expected to be incorporated into food or feed, through all stages of production and distribution" [22]. A more concise definition provided by The Codex Alimentarious Commission as "the ability to follow the movement of a food through specified stage(s) of production, processing and distribution" [23]. According to Bosona and Grebesenbet [24], food traceability defined as "part of logistics management that captures, stores, and transmits adequate information about food, feed, foodproducing is correct animal or substance at all stages in the food supply chain so that the product can be checked for safety and quality control, traced upward, and tracked downward at any time required". More selected definitions from several authors have summarized by Aung and Chang [6] that compare the differences among the definitions into terms of trace what, trace how, trace where, trace why, and trace when.

The objectives of a traceability system in the agricultural and food supply chain differs for farmers/growers, firms/processors and consumers [6]. For the farmers/growers, traceability is part of quality management system that can assist in continuous improvement and minimization of the impact of safety hazards. Traceability system can help firms/processors to improve supply management; facilitate trace back for food safety and quality; and differentiate and market foods with subtle or undetectable quality attributes. From a consumer perspective which is the focus in this study, traceability helps to build trust, peace of mind, and increase consumer confidence in the food buying decision.

A number of studies have been conducted to analyse consumer interest, preferences, willingness to pay, and also their behaviour toward traceable foods. Jin and Zhou [25] studied consumer interest in the information provided through food traceability systems by examining a national survey of Japanese consumers using a binary logit model and an ordered logit model. They found that the ratio of respondents who have accessed information through traceability systems is low. In regards to the kind of information through the traceability system, their study reported that respondents attached the most importance to harvest date, production method, and production method certification.

Based on a survey of consumers, Feng et al. [26] examined consumers' awareness of the quality and safety of fish products, purchasing behavior, and willingness to pay (WTP) for safe fish products in Beijing, China. The results show that among customers there is a shortage of knowledge concerning the safety of fish products, including processing, storage, and traceability systems. They doubt the quality of fishery products and are anxious about food safety. Their perception safety and the average price are the main determinants for Beijing consumers' WTP for the traceable products. The results also suggested that consumers are willing to pay a $6 \%$ premium for safe, traceable fish products over non-traced products, which 
may or may not be safe to consume. Similarly with previous study, Zhao et al. [5] investigated consumers' awareness, attitude and willingness to buy traceable food in two cities in China. They used a binary logistic regression model to identify the main factors influencing purchasing desires. The study found that consumers' evaluation of the safety of traceable food and acknowledgement of the importance of implementing food traceability determines their willingness to buy traceable food. It is likely that the willingness to consume traceable food will increase significantly with increased consumer awareness of the relationship between food traceability systems and food safety. The study also indicated that consumers' willingness-to-buy for traceable food is not generally high. They are only willing to pay $9 \%$ $12 \%$ more for traceable food than ordinary food. For those consumers unwilling to buy traceable food, there are two major reasons for this unwillingness: disbelief in traceable food information and high price.

Plessis et al. [27] studied the product attributes that influence the decision making process for consumers purchasing Karoo lamb meat in South Africa using a conjoint analysis. They found that the respondents have the greatest preference for lamb meat that can be traced back to the farm. The second most preferred lamb meat can be traced back to an abattoir and the least preferred lamb meat cannot be traced. The study indicates that price as an extrinsic attribute was the most important factor in the decision making process for consumers when purchasing lamb. Safety and quality were also relatively important with food safety clearly an important consideration for consumers when buying meat. Meanwhile, Gellynck et al. [28] investigated which attributes of traceability for Belgian consumers are the most important. They distinguished between functional and process attributes. Functional attributes are those related to the system efficiency such as organizational efficiency and chain monitoring, while process attributes are related to food processing such as information about origin or production methods. They suggested that indicating origin was the most preferred and useful piece of traceability information presented on labels.

In relation to consumer behaviour toward traceable food, Menozzi et al. [16] analyzed consumers' attitude and behaviour towards traceable food in two different European countries: Italy and France. For predicting consumers' intent to purchase traceable food, they found that attitudes drive the intention to purchase traceable chicken and honey in France, while trust affects the intention to purchase traceable chicken and honey in Italy. This study also indicated that preferences for purchasing traceable food may depend on food scares or safety hazards affecting specific food chains. In other studies, Chen and Huang [29] investigated whether or not the Food Traceability System (FTS) can lower an individual's perceived uncertainty and strengthen his/her purchase intention regarding fast foods. The results indicated that when a fast food store adopts FTS, consumers' perceived uncertainty can be reduced because both their perceived information asymmetry and fear of seller opportunism also fall, which in turn strengthens their purchase intentions regarding fast foods. In regards to environmental issues, Myae and Goddard [7] discovered which factors influence the degree of importance consumers place on traceability in guaranteeing environmentally sustainable production methods. In a country comparison (Canada, US and Japan), there are significant differences in countries' interests in traceability when verifying environmentally sustainable production practices and in the determinants for level of importance.

Socio-demographic characteristics may also influence consumer behaviour and preferences on the traceable food. According to Jin and Zhou [25]; gender, age, education, marital status and income are significantly related to the consumer interest to trace information through the traceability system in Japan. Their study show that young males and married respondents who have higher household incomes are more likely to trace information using the beef traceability system, whereas more educated females have a stronger desire to access more specific information related to fresh produce. Similarly, Wu et al. [30] also indicated that age, monthly family income and education level are significant factors in explaining the preferences and WTP of Chinese consumers for traceability information. They found that young consumers or consumers with high income and education levels had a high WTP for traceable foods. Furthermore, Menozzi et al. [16] found that household size in Italy and the number of children in households in France affect consumers' intention to purchase traceable chicken and honey, respectively. Having children is also indicated as a significant factor in explaining consumer willingness-tobuy on traceable foods in Beijing, China [31]. Meanwhile, housewife status has been found as significant factor affecting consumer WTP for traceability information in Taiwan [32]. Liu and Chen [33] found that place of purchase has a positive effect on consumers' WTP for traceable foods. Their results indicated that consumers who usually purchasing in supermarkets are more likely to buy traceable foods. Since most of the studies of consumers preferences or WTP for traceable food have been conducted in urban areas [16][26][31][32][34]; hence, it is also important in this study to ascertain whether consumers domicile in urban, suburban or rural areas have significant influence on their preferences on traceable food. Therefore, sociodemographic variables i.e.: age, gender, marital status, educational level, household size, income, employment status of women, domicile and having children younger than 18 years old were investigated in this study incorporate with factors influencing consumers' preferences for traceable foods such as safety concern, environmental concern, attitude toward traceable foods, trust in traceability information, certification, price; and other important motives for consumers to choose foods such as sensory appeal, healthiness, easiness and availability [35]. 


\section{Research Methods}

\subsection{Data and measurement}

Data were collected during February-March 2015 through face-to-face interviews by trained interviewers using a structured questionnaire. An interviewer gathered the information in a home visit in order to encourage a high level of cooperation, complete reporting and obtain high response. The surveys were completed throughout the Jabodetabek region (Jakarta, Bogor, Depok, Tangerang, and Bekasi). This location was selected to this study because there is a high concentration of modern retail markets that provide traceable or labelled FFV. The present study was focused on household sampling unit. Based on the report of Statistics Indonesia 2015, the household number in the research area is $7,178,528$. In determining sample size, Yamane [36] provides a simplified formula to calculate sample sizes, assume maximum variability $(\mathrm{p}=0.5)$ and desire a 95\% confidence level, as below:

$n=\frac{N}{1+N(e)^{2}}$

where $\mathrm{n}$ is the sample size, $\mathrm{N}$ is the population size, and e is the level of precision $( \pm 5 \%)$. Using this formula, the minimum sample of the study is 400 . Moreover, Comrey \& Lee [37] also provides the guidelines to assess the adequacy of the total sample size. They noted that samples of size 100 can give more than adequate reliability correlation coefficients. In this study, a total of 878 interviews were completed with residents aged 18 years and older. Respondents were selected based on convenience sampling, with the restriction that they were the main person responsible for purchasing FFV in the household. Therefore most of the respondents in this study are female, referred to the previous study in Indonesia which indicate women tend to take majority of the household purchase decisions [38]. The distribution of questionnaires was based on the representative proportion of the household number of each regency/city in Jabodetabek region (Table 1).

The questionnaire was divided into three sections. In the first section, the respondents were asked questions about their household's socio-economic and demographic characteristics (e.g., age, gender, education, marital status, household size, children in the household, employment status of the women in the households, domicile, monthly income level, FFV market channels choice and perception of traceable product price). These socio-demographic factors are hypothesized to influence consumers' preferences. The second section contained questions on consumers' dimensions/motives for purchasing food and their attitudes toward traceable fruit and vegetable (traceability can be ascertained by a product label). The respondents were asked some of the following statements based on their perception, for example: "I prefer to buy labelled fruits and vegetables because they are healthier and safer, are of better quality, the quality can be guaranteed, and the origin is known", "I prefer to buy food that is free of dangerous chemicals", "Products that are always available is important", "I believe that labelled products can really be traced back to the producer", "I consume fruits and vegetable to keep me and family healthy". The respondents were asked to rate each statement according to their perceived importance using a 7-point Likert scale ( $1=$ strongly unimportant/disagree and 7 = strongly important/agree). Although there has been much debate on what should be regarded as an optimal number of response categories of Likert type scales, Foddy [39] concludes that at least seven categories is required to ensure scale validity and reliability. Moreover, higher levels of scale granularity also offer more precise data, increase score variance, more meaningful statistical results, and fewer neutral and "uncertain" responses [40]. The third section contains questions on the consumers' preference for purchasing traceable FFV and their interest in information about traceable FFV. Respondents are asked for their preferences for the following 11 different kinds of information: (1) product brand, (2) nutrient content (3) guarantee for safety, (4) organic label, (5) name of producer; (6) best consume date (including harvest date and best before date), (7) environmental friendly production, (8) quality certification, (9) locally produced, (10) maturity, and (11) country of origin.

\subsection{Data analysis}

Descriptive analysis was conducted to show the respondent's socio-demographic variables and consumer interest in information provided by product labels, followed by an analysis of the two-stage process: a factor analysis and a binary logistic regression. First, factor analysis was applied using principle component analysis (PCA) method as a variable reduction procedure. The large number of different driving factors of consumers made it impossible to use each one as an explanatory variable in the subsequent analysis. As a preliminary analysis to ensure the suitability of conducting a factor analysis, this study used the KaiserMayer-Olkin (KMO) test and Bartlett's test of sphericity. The KMO test measures the adequacy of a sample in terms of the distribution of values for the execution of factor analysis; the acceptable values should be greater than 0.5 . Bartlett's test of sphericity determines if the correlation matrix is an identity matrix. Both tests indicated the suitability of the variables for a factor analysis [41].

Drawing from a study by Cornish [42], there are three main steps in a factor analysis. First, calculate the initial factor loadings that represent the correlations between the variables with the factor. In this study, the principle component method was used to carry out a principal components analysis. After the initial factor loadings were calculated, the second step of doing a factor rotation is conducted to find factors, which is easier to interpret. In this study, a principal component analysis using an orthogonal (varimax) rotation was chosen. The last step involves calculating the factor scores. We calculated the 
final factor scores using a regression-based approach. With this method, independent variables in the regression equation are the standardized observed values of the items in the estimated factors or components. These predictor variables are weighted by regression coefficients which are obtained by multiplying the inverse of the observed variable correlation matrix by the matrix of factor loadings [43]. To ensure the reliability of each factor, Cronbach's coefficient alpha was used to test the internal consistency among the items included in each factor. The reliability refers to the consistency of the results for different items in the test [44].

The second stage of the data analysis involves testing the main factors obtained from factor analysis and sociodemographic variables by using a binary logistic regression model. The logistic model was employed to analyse the determinants for consumers' preferences for traceable fruit and vegetable. Thus, whether a consumer prefers traceable products or not is explained by observable individual sociodemographic characteristics or factors within the logit framework. In this analysis, the major interest is the likelihood or probability of the outcome. The binary response in the study is whether the consumer prefers traceable FFV (represented as labelled products) or is not interested.

In the logistic regression, the important concept is the logit - the natural logarithm of an odds ratio [45]. Logistic regression solves these problems by applying a logit transformation to the dependent variable. Essentially, the logistic model predicts the logit of $\mathrm{Y}$ from $\mathrm{X}$. The logit is defined as the natural logarithm $(\ln )$ for odds of $Y$, and the odds are ratios of probabilities $(\pi)$ for $\mathrm{Y}$ happening to probabilities $(1-\pi)$ of $Y$ not happening. In the model, if $Y_{i}$ is a random variable (dichotomous), it can then be assumed that $Y_{i}$ takes the value of 1 or 0 , where 1 denotes the occurrence of the event and o otherwise. $X_{1}, \ldots$ are the explanatory variables related to the occurrence of this outcome. $X_{i}$ is the observed value of the explanatory variables for observation $i$. The logistic model can be written as follows:

$\operatorname{logit}\left(\pi_{i}\right)=\log \left(\frac{\pi_{i}}{1-\pi_{i}}\right)=\beta_{0}+\beta_{i} X_{i}$

Extending the logic of the simple logistic regression to multiple predictors, a complex logistic regression for consumers' preference of traceable fruit and vegetables was developed and is as described below:

$\operatorname{Logit}(Y)=\ln \left(\frac{\pi}{1-\pi}\right)=\alpha+\beta_{1} X_{1}+\beta_{2} X_{2}+\beta_{3} X_{3}+\cdots+$

$\beta_{n} X_{n}+\varepsilon$

where $\mathrm{Y}$ is the consumers' preference for purchasing traceable fruit and vegetable. In this model, $1=$ if consumer prefers traceable fruits and vegetables, $\mathrm{o}=$ otherwise, $\beta_{v}, \beta_{2}$, $\beta_{3}, \ldots, \beta_{n}$ are regression coefficient, and $\mathrm{X}_{1}, \mathrm{X}_{2}, \mathrm{X}_{3}, . ., \mathrm{X}_{\mathrm{n}}$ are the influencing factors. $X_{1}$ refers to the consumers' age (continuous), $X_{2}$ is gender, $X_{3}$ is domicile, $X_{4}$ is marital status, $X_{5}$ is household size, $X_{6}$ is the employment status of women in household, $X_{7}$ is having children in the household, $\mathrm{X}_{8}$ is the consumers' educational level, $\mathrm{X}_{9}$ is the consumers' income level per month, $X_{10}$ is the retail market's preference for daily FFV purchasing, $X_{11}$ is the degree of traceable FFV price acceptance and $X_{n}$ are the consumers' dimensions/motives for purchasing food and attitudes towards traceable FFV in the factor loading scores obtained from a factor analysis.

\section{Result and Discussion}

\subsection{Socio-demographic characteristic}

A total of 878 respondents who identified themselves as the food buyer of their household completed a questionnaire. In this study, $23 \%$ of respondents were in the 18 to 25 year age group, $27 \%$ were in the 26 to 35 year age group, $37 \%$ were in the 36 to 50 year age group and $13 \%$ were older than 51 years old. A majority of the respondents $(70.8 \%)$ reported that they were married. Respondents from families with children ( $<18$ years) accounted for $64.8 \%$ of the respondents. Households of 1 to 5 members made up $70.3 \%$ of the respondents with an average of four to five members in a household. The data shows that $11 \%$ of the respondents graduated from primary school (9 years), the majority of the respondents (46\%) graduated from secondary school, and $43 \%$ graduated from tertiary education or higher. The rate of employed woman in the households was determined to be $40 \%$. In terms of monthly household income, the revenue segment below 3000 million rupiah had the highest proportion at $48.4 \%$, while $41.8 \%$ for the households had a monthly income between 3000-7000 million rupiah. Most of the respondents (49.4\%) live in an urban domicile, $46.8 \%$ of the respondents reside in sub-urban areas and 3.9\% in rural areas. Almost $19 \%$ of the respondents identified themselves as modern shoppers and prefer modern retail channels when purchasing fruits and vegetables (hypermarkets, supermarkets, modern specialty stores and minimarkets), while more than $80 \%$ of the respondents usually choose traditional retail formats (wet markets, kiosks/warung and peddlers) for their daily FFV purchases. The majority of respondents perceive traceable products to be more expensive than ordinary products. Table 2 shows the sociodemographic statistics of the respondents and the variable definitions in the model.

\subsection{Dimensions of consumer preferences for food purchasing}

A factor analysis was applied to uncover the latent factors underlying the dimensions of consumers' preferences for food purchasing. As shown in Table 3, the KMO test resulted in a value of 0.884 and Bartlett's test of sphericity (Approx. Chi-square: 21708, df: 561, Sig. 0.00o). As mentioned before, the KMO test for sampling adequacy and Bartlett's test of sphericity were primarily performed on all the statements to confirm the appropriateness of applying a factor analysis. It also showed that the sampling adequacy is adequate. Based on the results of a rotated factor matrix, the 
eight most important factors were identified, namely: food safety concern, attitude toward traceable FFV, sensory appeal, environmentally concern, certification and brand, degree of trust, ease and availability, and health.

The safety concern factor accounted for $12.5 \%$ of the total variance. This factor is composed of five correlated statements: prefer to buy food free of dangerous chemicals, free of pathogen microorganisms, contains no additives, contains no artificial ingredients, and guaranteed safe. The attitude towards traceable FFV factor accounted for $11.45 \%$ of the total variance. This factor consisted of five items: traceable FFV are healthier, safer, of better quality, guaranteed, and are of known origin than ordinary products. The sensory appeal accounted for $11.28 \%$ of the total variance. It included six statements: I prefer to buy fruits and vegetables because they have a pleasant texture, good colour, smell nice, look fresh, taste good and have a nice appearance. The environmental concern factor contributes to $10.24 \%$ of the total variance. This factor consists of four statements: I am concerned about low carbon emissions, environmentally friendly packaging, efficient use of resources during production, and environmental input. The brand and certification factor accounted for $9.69 \%$ of the total variance. There were five statements in this factor: I prefer to buy food from wellknown brands, brand with a good reputation, have clear, complete labels, certification from reputable institutions, and are quality certified. The trust factor accounted for $6.91 \%$ of the total variance. This factor is made up of three variables: I believe that the labelled product can really be traced back to the producer, I trust the information on the label and I trust certified products. The ease and availability factor explained $6.64 \%$ of the total variance. This factor consisted of three variables: I prefer to purchase food that is easy to prepare, always available and easy to get. The health factor accounted for $5.31 \%$ of the total variance. This factor included two statements: I consume food to keep my family and I healthy and I consume food that high in fibre and vitamins.

These eight factors combined explained $74.03 \%$ of the total variance (Table 4). The factor loading for eight factors ranged from 0.629 to 0.898 . The Cronbach's alpha was applied to test the reliability of variables. The results of the test category showed clear coherence amongst each category, with the food safety factor possessing an alpha value of 0.903 , the attitude towards traceable FFV possessing an alpha value of 0.916 , the sensory appeal factor possessing an alpha value of 0.877 , the environmental concern factor possessing an alpha value of 0.925 , the brand and certification factor possessing an alpha value of 0.887 , the degree of trust possessing an alpha value of 0.873 , the ease and availability factor possessing an alpha value of 0.820 and the health factor possessing an alpha value of 0.859 .

\subsection{Consumers' interest on the product label information}

Respondents were asked about their interest in different kinds of label information. Each question only had two possible answers ("want to know" or "do not want to know"). Fig. 2 shows the ranking of consumers' interest in certain information. The findings showed that $90.53 \%$ of respondents need information on the harvest date and best before date, $88.05 \%$ need information on nutrient content, $87.03 \%$ need information that guarantees safety, $86.70 \%$ want to know the product brand, $74.07 \%$ want to know if the products are locally produced, $69.22 \%$ want to know the maturity of plant (for fruits), $66.52 \%$ need information about quality certification, $63.59 \%$ want to know the country of origin for imported products, $61.89 \%$ want to know that the production method is environmental friendly (also related to the production input), 60.65\% want to know whether the products are organic or conventionally grown, and $50.06 \%$ of the respondents need information on the producer's name.

The results are generally in similar with findings from previous studies. According to Takahashi et al.[46] in a study that investigate the intent for the production and circulation of information in respect to vegetables, it was found that $74 \%$ of respondents need information on the production method, $64.8 \%$ need information on the pesticides (drugs) used in production, 61.3\% need information on the harvest date, $39.8 \%$ want information on nutrition, $33.8 \%$ want to know about fertilizers (feeds) used in production, while only $24.8 \%$ want to know the name of the producer. Meanwhile, Jin and Zhou [25] found that the top three kinds of information that were needed by consumers are harvest date, production method, and production method certification. They also found that the name of the producer was the information of least interest.

\subsection{Determinants of consumer preferences}

Before creating the model, we conducted a statistical analysis to determine whether respondents had considered the information on the label and preferred to buy traceable FFV. The results indicate that more than forty percent (44\%) of respondents prefer to buy traceable/labelled FFV, while $56 \%$ prefer to buy ordinary FFV. In the binary logistic regression model, this question is defined as the dependent variable with the assessment ( $1=$ consider buying traceable product, $\mathrm{o}=$ ordinary product/otherwise). Table 5 presents the probabilities for the results of the computed change, including the maximum-likelihood estimated coefficients, change in probability-likelihood-ratio test, Nagelkerke $\mathrm{R}^{2}$, and the model-prediction success. The likelihood-ratio test, which measures the significance of the model, which had a final score of 907.665 , was significant, suggesting that there is a relationship between the consumers' preference and the suggested independent variable. The Nagelkerke $R^{2}$ was found to be 0.371 , which indicates that the model is fit and almost $37 \%$ of the variation in the dependent variable is 
explained by the model. The Chi-square value was found to be 11.545 with an observed significance of 0.001 level (determined through a Hosmer and Lemeshow test), which indicates that the null hypothesis was rejected by the model. This means there is no difference between the observed and predicted values. The model has a coefficient of predicting power of approximately $74.8 \%$. Furthermore, we estimated the variance inflation factors (VIF) and tolerance for all variables in order to check multicollinearity. The VIF statistics for the models are smaller than 10 (the largest value is $\mathbf{1 . 8 5 5}$ of all variables in the model) and each independent variable demonstrated high levels of tolerance (all above o.2), thus indicating the absence of multicollinearity [47].

Based on the model estimation as shown in Table 5 and with respect to the results of the socio-demographic variables, there are three variables that have a statistically significant impact on consumers' purchase preferences for traceable FFV (EDU, RETAIL, and PRICE variables). The EDU variable is statistically significant at the $1 \%$ level and is positively associated with interest in traceable/labelled FFV. In reference to the odds ratio $(\operatorname{Exp}(\beta))$, the value indicates that well-educated respondents are 1.511 times more likely to consider buying traceable/labelled FFV than lower-educated respondents. Similarly, the RETAIL variable is a positive value that is also statistically significant at the $1 \%$ level. The likelihood of respondents purchasing traceable/labelled FFV products is $\mathbf{1 . 8 2 7}$ times more for respondents who were classified as modern retail shoppers than traditional retail shoppers. The estimated coefficient for the PRICE variable is negative and statistically significant at the $1 \%$ level which implies that the respondents who perceive traceable/labelled FFV to be more expensive are 0.569 less likely to buy the product. In other words, they prefer to buy ordinary product. On the other hand, we did not find statistically significant results for AGE, GEND, DOM, MARI, SIZE, CHILD, EMPLOY, and INCOME, which means that these variables have no impact on consumers' preferences for traceable/labelled FFV.

Furthermore, in regards to the variables constructed from the factor analysis, six of eight variables had a statistically significant impact on consumers' purchasing preferences for traceable FFV. These were the SAFETY, ATTITUDE, ENVI, CERTI, TRUST, and EASY variables. The estimated coefficient for the SAFETY variable is positive and has a statistically significant at the $10 \%$ level, which implies that respondents who have a higher concern for food safety are more likely to consider buying traceable/labelled FFV than respondents who have lower concern for food safety. The ATTITUDE variable is statistically significant at the $1 \%$ level. The positive coefficient implies that respondents who have a positive attitude toward traceable/labelled FFV products prefer to buy them. The positive ENVI variable is statistically significant at the $1 \%$ levels, which implies that respondents who have a higher concern for environmental issues are more likely to consider buying traceable/labelled
FFV than respondents who are less concerned with environmental issues.

The estimated coefficient for the positive CERTI variable is statistically significant at the $1 \%$ level. The highest value of the odds ratio, which is positive, implies that brand and certification are the highest determinants of consumers' preference to consider buying traceable/labelled FFV. This indicates that respondents, who consider brand and certification important qualities when purchasing FFV, prefer traceable/labelled products compared with consumers who think the brand and certification is not important. The TRUST variable is statistically significant at the $1 \%$ level. The positive coefficient implies that respondents who believe in the validity of the information on the label will consider buying traceable/labelled FFV. Meanwhile, the negative EASY variable is statistically significant, which indicates that the respondents are 0.768 less likely to purchase traceable/labelled FFV when the products are not easy to get/prepare or not always available.

\section{Conclusions}

The objective of this study was to illustrate consumers' preferences for traceable/labelled FFV, their interest in information provided on product labels and also to find out what determines consumers' choice toward purchasing traceable/labelled FFV products. The results of this study shows that the number of respondents who buy traceable/labelled product is lower than respondents who prefer to buy ordinary products. The findings also show the five kinds of information that most consumers want to know (harvest date and best before date, nutrient content, safety guarantee, product brand, and if the product is locally produced). A binary logit model indicated that consumers' preference is determined by education level, FFV retail choice, price, food safety concerns, attitudes toward traceable/labelled products, environmental concerns, brand and certification, degree of trust, and ease and availability. Traceable/labelled FFV are more likely to be purchased by consumers who are highly educated, usually purchase FFV in modern retail markets and perceived the traceable price is not expensive. Potential buyers for traceable/labelled FFV are also identified as consumers who are concerned with food safety and environmental issues, have positive attitude and confidence toward traceable/labelled FFV and presume that brand and certification are important factors when purchasing food. Meanwhile, the respondents who are from lower-educated households usually purchase FFV in traditional retail markets where prices are low, and presume that ease and availability are important factors, and as a result prefer buy ordinary products.

Based on the findings of this study, despite consumer preference towards traceable FFV is still low, but it has emerged a consumer interest in information from traceable FFV. It also emerges the necessity to effectively communicate to consumers what traceability is and to strengthen how it guarantees more safer, healthier, better in 
quality or/and environmental friendly for FFV products throughout implementing educational programs targeting different segments of consumers. Furthermore, social media platforms can be an effective communication tool since the growth of Indonesian consuming class will be dominated by young population, well-educated and middle income class households who have higher attention on food safety, health and environmental issues [48]. It is also needed to develop quality assurance schemes that use labels or develop information and communication technologies (e.g. mobile device application) that make information recorded in food traceability systems easily available and understood by consumers. To reduce higher price of traceable FFV that explained as one of the obstacles, programs that financially help the stakeholders in the FFV supply chain is very important. Traceability has reduced consumer perceived risk and increased their trust in the stakeholders of the FFV chain. This is because traceability gives consumers the possibility of checking or their perceived control on what happening in the food system [3].

\section{Acknowledgements}

We thank for Directorate General for Higher Education (DIKTI) from the Indonesian Ministry for Higher Education, Research and Technology for their financial support.

\section{References}

[1] Aung, M. M.; Chang, Y. S. Traceability in a food supply chain: Safety and quality perspectives. Food Control 2014; 39: 172-184.

[2] Hobbs, J. E. Information asymmetry and the role of traceability systems. Agribusiness 2004; 20: 397-415.

[3] Hansstein, F. V. Consumer Knowledge and Attitudes towards Food Traceability: A Comparison between the European Union, China and North America. In 2014 International Conference on Food Security and Nutrition; IACSIT Press: Singapore, 2014; Vol. 67, pp. 114-118.

[4] Bektas, Z. K.; Miran, B.; Uysal, O. K.; Gunden, C. Consumer awareness for food safety in Turkey. Bulg. J. Agric. Sci. 2011; 17: $470-483$.

[5] Zhao, R.; Qiao, J.; Chen, Y. Influencing factors of consumer willingness-to-buy traceable foods: An analysis of survey data from two Chinese cities. Agric. Agric. Sci. Procedia 2010, 1, 334343 .

[6] Aung, M. M.; Chang, Y. S. Traceability in a food supply chain: Safety and quality perspectives. Food Control 2014; 39: 172-184.

[7] Myae, A. C.; Goddard, E. Importance of traceability for sustainable production: a cross-country comparison. Int. J. Consum. Stud. 2012; 36: 192-202.

[8] Vanany, I.; Andri, K. B.; Mardiyanto, R.; Puspita, N. F.; Winarsih, W. H. An Electronic Traceability System for an Indonesian Fresh Fruit Supply Chain. IPTEK J. Proceeding Ser. 2014, 1, 4-7.

[9] Sabbe, S. Consumer perception and behaviour towards tropical fruits in Belgium, 2009.

[10] Engel, J. F.; Blackwell, D. R. Consumer Behavior. New York Holt, Rinehart Winst. 1995.

[11] Darby, M. R.; Karni, E. Free Competition and the Optimal Amount of Fraud. J. Law Econ. 1973; 16: 67-88.

[12] Brunsø, K.; Fjord, T. A.; Grunert, K. G. Consumers 'Food Choice and Quality Perception; 2002.
[13] Grunert, K. G.; Bredahl, L.; Brunsø, K. Consumer perception of meat quality and implications for product development in the meat sector-a review. Meat Sci. 2004; 66: 259-272.

[14] Moser, R.; Raffaelli, R.; Thilmany-McFadden, D. Consumer preferences for fruit and vegetables with credence-based attributes: A review. Int. Food Agribus. Manag. Rev. 2011; 14: 121142.

[15] Hobbs, J. E.; Bailey, D.; Dickinson, D. L.; Haghiri, M. Traceability in the Canadian Red Meat Sector: Do Consumers Care? Can. J. Agric. Econ. 2005; 53: 47-65.

[16] Menozzi, D.; Halawany-Darson, R.; Mora, C.; Giraud, G. Motives towards traceable food choice: A comparison between French and Italian consumers. Food Control 2013; 49: 40-48.

[17] Campbell-Gibbons, H. Securing a sustainable British horticulture industry. Nutr. Bull. 2011; 36: 443-448.

[18] Kader, A. A. Handling of horticultural perishables in developing vs. developed countries. In Acta Horticulturae; 2010; Vol. 877, pp. 121-126.

[19] Jairath, M. S.; Purohit, P. Food safety regulatory compliance in india: A challenge to enhance agri-businesses. Ind. J. of Agric. Econ. 2013; 68: 431-448.

[20] ISO 8402; 1994.

[21] ISO 9000: 2005; 2005.

[22] European Parliament and Council Regulation (EC) No 178/2002. Laying down the general principles and requirements of food law, establishing the European Food Safety Authority and laying down procedures in matters of food safety; 2002; pp. L31/1-24.

[23] WHO/FAO Codex Alimentarius Commission: Procedural Manual (21st ed.); 2013.

[24] Bosona, T.; Gebresenbet, G. Food traceability as an integral part of logistics management in food and agricultural supply chain. Food Control 2013; 33: 32-48.

[25] Jin, S.; Zhou, L. Consumer interest in information provided by food traceability systems in Japan. Food Qual. Prefer. 2014; 36: 144-152.

[26]Wang, F.; Zhang, J.; Mu, W.; Fu, Z.; Zhang, X. Consumers' perception toward quality and safety of fishery products, Beijing, China. Food Control 2009; 20: 918-922.

[27] Plessis, H. J.; du Rand, G. E. The significance of traceability in consumer decision making towards Karoo lamb. Food Res. Int. 2012; 47: 210-217.

[28] Gellynck, X.; Verbeke, W.; Vermeire, B. Pathways to increase consumer trust in meat as a safe and wholesome food. Meat Sci. 2006; 74: 161-71.

[29] Chen, M. F.; Huang, C. H. The impacts of the food traceability system and consumer involvement on consumers' purchase intentions toward fast foods. Food Control 2013; 33: 313-319.

[30]Wu, L.; Wang, S.; Zhu, D.; Hu, W.; Wang, H. Chinese consumers' preferences and willingness to pay for traceable food quality and safety attributes: The case of pork. China Econ. Rev. 2015; 35: 121-136.

[31] $\mathrm{Xu}, \mathrm{L}$; $\mathrm{Wu}, \mathrm{L}$. Food safety and consumer willingness to pay for certified traceable food in China. J. Sci. Food Agric. 2010; 9o: 1368-1373.

[32] Yang, S.-H.; Monteiro, D. S. What's in a Price? The Impact of Starting Point Bias in WTP for Information in Taiwanese Wet Markets. In The Agricultural \& Applied Economics Association's 2016 AAEA Annual Meeting; Boston, MA, 2016.

[33] Liu, H.-C.; Liu, L.; Liu, N.; Mao, L.-X. Risk evaluation in failure mode and effects analysis with extended VIKOR method under fuzzy environment. Expert Syst. Appl. 2012; 39: 12926-12934.

[34] Guifeng, L.; Honghua, C. An empirical study of consumers willingness to pay for traceable food in Beijing, Shanghai and 
Jinan of China. African J. Bus. Manag. 2015; 9: 96-102.

[35] Steptoe, A.; Pollard, T. M.; Wardle, J. Development of a measure of the motives underlying the selection of food: the food choice questionnaire. Appetite 1995; 25: 267-284.

[36] Yamane, T. Statistics: An introductory analysis.; New York, 1967.

[37] Comrey, A. L.; Lee, H. B. A first course in factor analysis; Psychology Press: Hillsdale, New Jersey, 2013.

[38] Markplus Insight Women cast strongest influence in household buying decisions http://markplusinsight.com/article/detail/33/women-caststrongest-influence-in-household-buying-decisions (accessed Aug 12, 2015).

[39] Foddy, W. Constructing questions for interviews and questionnaires: theory and practice in social research; Cambridge University Press: Cambridge, UK, 1993.

[40]Pearse, N. Deciding on the scale granularity of response categories of likert type scales: The case of a 21-point scale. Electron. J. Bus. Res. Methods 2011; 9: 159-171.

[41] Ghosh, S.; Jintanapakanont, J. Identifying and assessing the critical risk factors in an underground rail project in Thailand: A factor analysis approach. Int. J. Proj. Manag. 2004; 22: 633643.

[42] Cornish, R. Statistics: Factor Analysis; 2007.

[43] Distefano, C.; Mîndril, D. Understanding and Using Factor Scores: Considerations for the Applied Researcher. Pract. Assessment, Res. Eval. 2009; 14: 1-11.

[44]Carmines, E. G.; Zeller, R. A. Reliability and validity assessment; Sage publications, 1979; Vol. 17.

[45] Peng, C.-Y. J.; Lee, K. L.; Ingersoll, G. M. An Introduction to Logistic Regression Analysis and Reporting. J. Educ. Res. 2002; 96: $3^{-14}$.

[46]Takahashi, K.; Kouno, Y.; Oura, Y. An Asymmetry of Information Needs and Disclosure Testing the Non-parametric Method on the Food Chain. J. Food Syst. Res. 2008; 14: 2-12.

[47] Hair, J. F.; Black, W. C.; Babin, B. J.; Anderson, R. E. Multivariate Data Analysis; Seventh.; Pearson Education, Inc: New Jersey, 2010.
[48]Razdan, R.; Das, M.; Sohoni, A. The evolving Indonesian consumer. 2013, 1-25. 
Table 1 The household number in the research area and the distribution of respondents

\begin{tabular}{lcccc}
\hline \multicolumn{1}{c}{ Regency/City } & $\begin{array}{c}\text { Number of } \\
\text { household }\end{array}$ & $\begin{array}{c}\text { Percentage of } \\
\text { household }\end{array}$ & $\begin{array}{c}\text { Number of } \\
\text { respondents }\end{array}$ & $\begin{array}{c}\text { Percentage of } \\
\text { respondents }\end{array}$ \\
\hline Jakarta \& Depok City & $3,226,314$ & $45 \%$ & 379 & $43 \%$ \\
Bogor City \& Bogor Regency & $1,545,800$ & $22 \%$ & 238 & $27 \%$ \\
Tangerang City \& South of Tangerang City & 909,085 & $13 \%$ & 124 & $14 \%$ \\
Bekasi City \& Bekasi Regency & $1,506,329$ & $21 \%$ & 137 & $16 \%$ \\
Total & $7,187,528$ & $100 \%$ & 878 & $100 \%$ \\
\hline
\end{tabular}

${ }^{\text {a }}$ Source: BPS-Statistic Indonesia, 2015

Table 2 Socio-demographic characteristics of the respondents and variable definitions

\begin{tabular}{|c|c|c|c|c|c|}
\hline \multirow[b]{2}{*}{ Characteristics } & \multirow[b]{2}{*}{ Percentage } & \multicolumn{4}{|c|}{ Variable definition in the model } \\
\hline & & Variable & $\begin{array}{l}\text { Value } \\
\text { assignment }\end{array}$ & Mean & SD \\
\hline Age & & AGE & & 2.40 & 0.974 \\
\hline $18-25$ & $22.7 \%$ & & $=1$ & & \\
\hline $26-35$ & $26.9 \%$ & & $=2$ & & \\
\hline $35-50$ & $37.8 \%$ & & $=3$ & & \\
\hline $51+$ & $12.6 \%$ & & $=4$ & & \\
\hline Gender & & GEND & & 0.88 & 0.569 \\
\hline Male & $12.1 \%$ & & $=0$ & & \\
\hline Female & $87.9 \%$ & & $=1$ & & \\
\hline Education level & & EDU & & 2.32 & 0.659 \\
\hline Primary (9 years) or lower & $10.8 \%$ & & $=1$ & & \\
\hline Secondary & $46.6 \%$ & & $=2$ & & \\
\hline Tertiary or higher & $42.6 \%$ & & $=3$ & & \\
\hline Marital status & & MARI & & 0.71 & 0.455 \\
\hline Single & $29.2 \%$ & & $=0$ & & \\
\hline Married & $70.8 \%$ & & $=1$ & & \\
\hline Household size (person) & & SIZE & continues & 4.59 & 2.173 \\
\hline 1 & $10.8 \%$ & & & & \\
\hline 2 & $4.2 \%$ & & & & \\
\hline 3 & $12.9 \%$ & & & & \\
\hline 4 & $19.9 \%$ & & & & \\
\hline 5 & $22.4 \%$ & & & & \\
\hline$\geq 6$ & $29.7 \%$ & & & & \\
\hline Children in the household ( $<18$ years) & & CHILD & & 0.65 & 0.478 \\
\hline No & $35.2 \%$ & & $=0$ & & \\
\hline Yes & $64.8 \%$ & & $=1$ & & \\
\hline Domicile & & DOM & & 1.54 & 0.569 \\
\hline Urban & $49 \cdot 4 \%$ & & $=1$ & & \\
\hline Sub-urban & $46.8 \%$ & & $=2$ & & \\
\hline Rural & $3.9 \%$ & & $=3$ & & \\
\hline Employment status of women & & EMPLOY & & 0.40 & 0.490 \\
\hline Employed & $40.1 \%$ & & $=1$ & & \\
\hline Unemployed (included housewife) & $59.9 \%$ & & $=0$ & & \\
\hline Monthly household income level & & INCOME & & 1.61 & 0.658 \\
\hline$<3000$ million rupiah & $48.4 \%$ & & $=1$ & & \\
\hline 30oo-70oo million rupiah & $41.8 \%$ & & $=2$ & & \\
\hline$>7000$ million rupiah & $9.8 \%$ & & $=3$ & & \\
\hline FFV retail choice & & RETAIL & & 0.19 & 0.390 \\
\hline Traditional retail market & $81.3 \%$ & & $=0$ & & \\
\hline Modern retail market & $18.7 \%$ & & $=1$ & & \\
\hline Perception of traceable FFV price & & PRICE & & 0.82 & 0.384 \\
\hline Not different than ordinary FFV & $17.9 \%$ & & $=0$ & & \\
\hline More expensive & $82.1 \%$ & & $=1$ & & \\
\hline
\end{tabular}


Table 3 Kaiser-Meyer-Olkin and Bartlett's Test

\begin{tabular}{lrr}
\hline Kaiser-Meyer-Olkin Measure of Sampling Adequacy. & & 0.884 \\
\hline Bartlett's Test of Sphericity & Approx. Chi-Square & 21708.072 \\
& Df & 561 \\
& Sig. & 0.000 \\
\hline
\end{tabular}

Table 4 Summary of the factor analysis result

\begin{tabular}{|c|c|c|c|c|c|}
\hline Factor & Variables included in the factor & $\begin{array}{l}\text { Factor } \\
\text { loadings }\end{array}$ & $\begin{array}{l}\text { Cronbach' } \\
\text { s alpha }\end{array}$ & $\begin{array}{c}\text { Variance } \\
\text { explained } \\
(\%)\end{array}$ & $\begin{array}{c}\text { Variable } \\
\text { definition } \\
\text { in the } \\
\text { model }\end{array}$ \\
\hline \multirow[t]{6}{*}{ Food safety concern } & Free of dangerous chemicals & 0.833 & \multirow{6}{*}{0.903} & \multirow{6}{*}{12.51} & \multirow{6}{*}{ SAFETY } \\
\hline & Free of pathogen microorganisms & 0.829 & & & \\
\hline & Contains no additive & 0.778 & & & \\
\hline & Contains no artificial ingredients & 0.766 & & & \\
\hline & Safety guaranteed & 0.724 & & & \\
\hline & Natural production & 0.629 & & & \\
\hline \multirow[t]{5}{*}{$\begin{array}{l}\text { Attitude towards } \\
\text { traceable FFV }\end{array}$} & $\begin{array}{l}\text { Traceable FFV is healthier than } \\
\text { ordinary product }\end{array}$ & 0.898 & \multirow{5}{*}{0.916} & \multirow{5}{*}{11.45} & \multirow{5}{*}{ ATTITUDE } \\
\hline & $\begin{array}{l}\text { Traceable FFV is safer than } \\
\text { ordinary product }\end{array}$ & 0.897 & & & \\
\hline & $\begin{array}{l}\text { Traceable FFV is better quality } \\
\text { than ordinary product }\end{array}$ & 0.837 & & & \\
\hline & $\begin{array}{l}\text { Traceable FFV is guaranteed than } \\
\text { ordinary product }\end{array}$ & 0.828 & & & \\
\hline & Traceable FFV is known of origin & 0.753 & & & \\
\hline \multirow[t]{6}{*}{ Sensory appeal } & Have a pleasant texture & 0.796 & \multirow{6}{*}{0.877} & \multirow{6}{*}{11.28} & \multirow{6}{*}{ SENSORY } \\
\hline & Good colour & 0.796 & & & \\
\hline & Smells nice & 0.771 & & & \\
\hline & Looks fresh & 0.710 & & & \\
\hline & Tastes good & 0.694 & & & \\
\hline & Looks nice in appearance & 0.680 & & & \\
\hline \multirow{4}{*}{$\begin{array}{l}\text { Environmental } \\
\text { concern }\end{array}$} & Low carbon emissions & 0.854 & \multirow{4}{*}{0.925} & \multirow{4}{*}{10.24} & \multirow{4}{*}{ ENVI } \\
\hline & $\begin{array}{l}\text { Uses environmentally friendly } \\
\text { packaging }\end{array}$ & 0.835 & & & \\
\hline & Efficient use of resources & 0.826 & & & \\
\hline & Environmental inputs & 0.755 & & & \\
\hline \multirow[t]{5}{*}{ Brand and certification } & Well-known brand & 0.840 & \multirow{5}{*}{0.887} & \multirow{5}{*}{9.69} & \multirow{5}{*}{ CERTI } \\
\hline & Brand has good reputation & 0.837 & & & \\
\hline & $\begin{array}{l}\text { Clear label with complete } \\
\text { information }\end{array}$ & 0.722 & & & \\
\hline & $\begin{array}{l}\text { Certification from reputable } \\
\text { institution }\end{array}$ & 0.716 & & & \\
\hline & Quality certified & 0.698 & & & \\
\hline \multirow[t]{3}{*}{ Degree of Trust } & $\begin{array}{l}\text { I believe that the labelled product } \\
\text { is really can be trace into producer }\end{array}$ & 0.881 & \multirow{3}{*}{0.873} & \multirow{3}{*}{6.91} & \multirow{3}{*}{ TRUST } \\
\hline & $\begin{array}{l}\text { I trust with the information in the } \\
\text { label }\end{array}$ & 0.856 & & & \\
\hline & I trust with the certified product & 0.811 & & & \\
\hline \multirow{3}{*}{$\begin{array}{l}\text { Easiness } \\
\text { availability }\end{array}$} & Easy to prepare & 0.808 & \multirow{3}{*}{0.820} & \multirow{3}{*}{6.64} & \multirow{3}{*}{ EASY } \\
\hline & Always available & 0.806 & & & \\
\hline & Easy to get & 0.786 & & & \\
\hline \multirow[t]{2}{*}{ Health concern } & Keeps me and my family healthy & 0.806 & & & \\
\hline & $\begin{array}{l}\text { High in fiber and contains a lot of } \\
\text { vitamins }\end{array}$ & 0.743 & 0.859 & $5 \cdot 31$ & HEALTH \\
\hline
\end{tabular}




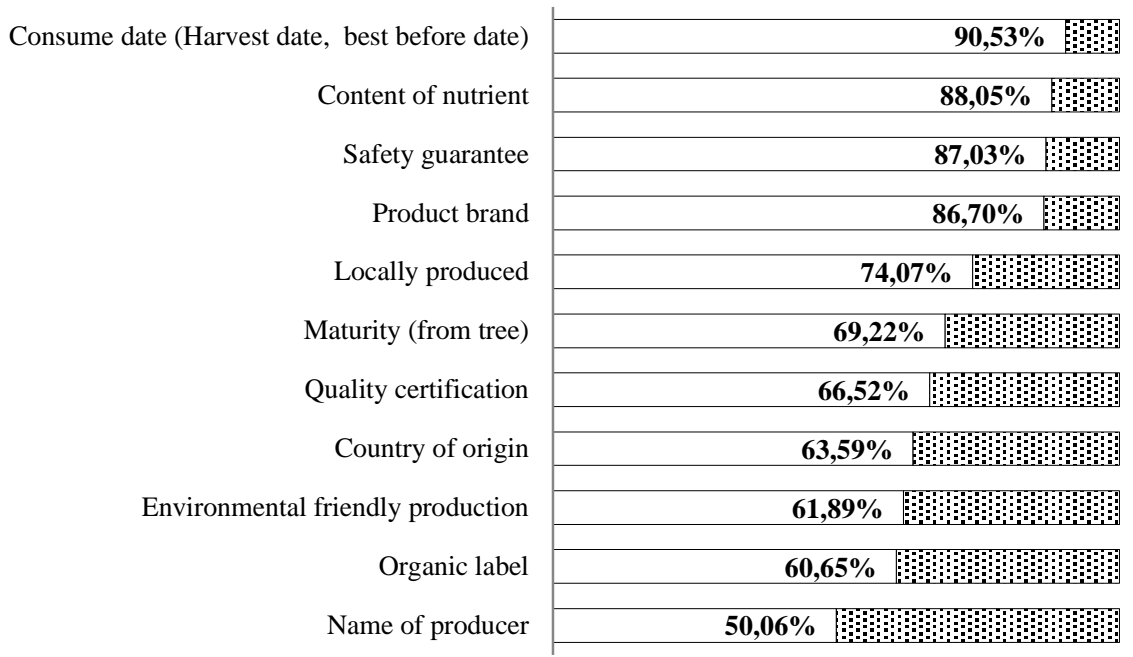

$0 \% \quad 10 \% 20 \% 30 \% \quad 40 \% 50 \% \quad 60 \% \quad 70 \% 80 \% 90 \% 100 \%$

$\square$ Want to know $\quad$ Gon't want to know

Figure 1 Consumers' interest for information of product label

Table 5 Estimated logit model for consumers' preference on the traceable FFV

\begin{tabular}{|c|c|c|c|c|}
\hline & $\beta$ & S.E. & Sig. & $\operatorname{Exp}(\beta)$ \\
\hline AGE & -0.132 & 0.116 & 0.256 & 0.876 \\
\hline GEND & 0.030 & 0.272 & 0.913 & 1.030 \\
\hline DOMI & 0.182 & 0.148 & 0.219 & 1.199 \\
\hline MARI & 0.130 & 0.248 & 0.598 & 1.139 \\
\hline SIZE & -0.024 & 0.045 & 0.590 & 0.976 \\
\hline EMPLOY & -0.097 & 0.195 & 0.618 & 0.907 \\
\hline CHILD & 0.027 & 0.191 & 0.889 & 1.027 \\
\hline EDU & $0.413^{* * *}$ & 0.156 & 0.008 & 1.511 \\
\hline INCOME & -0.209 & 0.152 & 0.169 & 0.811 \\
\hline RETAIL & $0.603^{* * *}$ & 0.218 & 0.006 & 1.827 \\
\hline PRICE & $-0.564^{* * *}$ & 0.215 & 0.009 & 0.569 \\
\hline SAFETY & $0.153^{*}$ & 0.086 & 0.076 & 1.165 \\
\hline ATTITUDE & $0.670^{* * *}$ & 0.093 & 0.000 & 1.954 \\
\hline SENSORY & -0.094 & 0.082 & 0.250 & 0.910 \\
\hline ENVI & $0.545^{* * *}$ & 0.095 & o.ooo & 1.725 \\
\hline CERTI & $0.892^{* * *}$ & 0.094 & 0.000 & 2.440 \\
\hline TRUST & $0.360^{* * *}$ & 0.088 & 0.000 & 1.434 \\
\hline EASY & $-0.264^{* * *}$ & 0.083 & 0.001 & 0.768 \\
\hline HEALTH & 0.054 & 0.082 & 0.506 & 1.056 \\
\hline Constant & -0.591 & 0.603 & 0.327 & 0.554 \\
\hline $\mathrm{L}_{\mathrm{o}}=-2$ Log Likelihood (initial) & $1204 \cdot 338$ & & & \\
\hline $\mathrm{L}_{1}=-2$ Log Likelihood (final) & 907.665 & & & \\
\hline Cox and Snell R square & 0.287 & & & \\
\hline Nagelkerke R Square & 0.384 & & & \\
\hline$x^{2}$ & $11.545^{* * *}$ & & & \\
\hline Prediction accuracy & $74.8 \%$ & & & \\
\hline
\end{tabular}

